\title{
A Situational Analysis of English Language Learning among Eastern Indonesian Students
}

\author{
Mozes Kurniawan \\ Faculty of Teacher Training and Education \\ Universitas Kristen Satya Wacana \\ Salatiga, Indonesia \\ mailbox.mozeskurniawan@gmail.com
}

\author{
Elvira Hoesein Radia \\ Faculty of Teacher Training and Education \\ Universitas Kristen Satya Wacana \\ Salatiga, Indonesia \\ vera_elvira@yahoo.com
}

\begin{abstract}
Nowadays, English is widely spread for communication in the world. It is also considered as the first formal language for international communities. The importance of English as a global language is also felt by a lot of countries, in this case, Indonesia. As a part of ASEAN Economic Community, Indonesian people should be able to use English since it becomes the medium of communication in almost aspects of life namely finance, mass media, health, education and others. However, Indonesia still encounters challenges particularly in rural regions in the eastern part of this country. The challenges are related to the lack of English competence due to some factors. This study will reveal possible factors affecting Eastern Indonesian students' lack of English competence based on situational analysis of some categories such as: students' competence, English Language Teaching (ELT) management and ELT resources. Those ideas will be presented based on the research of one-year college students whose origin is from Eastern Indonesia such as: Ambon, Maluku, Papua, etc. The data gathered is analyzed qualitatively in a form of substantial categories description. Finally, the result shows that English education in Eastern Indonesia need to be maximized in the area of student' competence, teachers' management skill and the use of resources.
\end{abstract}

Keywords- English as A Global Language, English Competence, English Language Teaching, Management

\section{INTRODUCTION}

English, is perceived as an important language for almost aspects of life. The reason is, surely, most of the countries in the world use English as the medium of communication and make it as the first formal language. A research data presented that English and Chinese were spoken by the widest language speakers. There were approximately 1123 million people speaking English [1]. While the other research statistics put English as the most frequent language in internet [2]. More than a half (75\%) of the world's mail language uses English as the medium of correspondence. English is also used as $50 \%$ of the world's newspaper language and over $50 \%$ of the world's scientific and technical publications language [3]. The wide usage of English leads to the demands of this language internationally. English, that is widely used, understood by most of countries and served as a global mean of communication, is called by English as a global language. As a global language, English plays important role such as: lingua franca, i.e. language used by countries whose first language is different; business English, i.e. English used for negotiating, decision making and building commercial relations; mass media narration, i.e. language used to explain, promote and/or describe something indirectly from mass media communication tools [4]; and others. That English places a certain position among people and enables them to reach wider achievements globally is begun by teaching it in educational setting. English should be needed by countries and taught as additional language learning though it is not the official language of some countries since it has acceptation power in global community [5].

Due to its importance, a lot of people among nations struggle to master English to have a qualified competence. They may be learning English by following school curriculum. They can also learn it by joining intensive English language course while some others become autodidact. People believe by mastering English, they are able to compete globally and have wider opportunities to increase their career [6]. Opportunities and career improvements by mastering English is believed as a golden key to success by most of nations [7]. As a part of ASEAN Economic Community, Indonesian people should also be able to use English since it becomes the medium of communication in almost aspects of life namely finance, mass media, health, education and many more. The urgent need of English competence highlighted by Indonesian government from Government Regulation number 19, 2015 that English was determined as one of required subjects for national examination. Indonesia, from the curriculum of 1994, have already introduced English to schoolers from early level of study (fourth year of elementary school) until the highest one (postgraduate school) [8]. These efforts were expected to result qualified Indonesian students' English competence.

Nonetheless, the expectation of having qualified Indonesian students' English competence is not in accordance with the rea fact of its people. Indonesian people still encounter problems in mastering English. Some researchers proposed ideas about Indonesian people lack of English competence especially those who live in Eastern Indonesia. Indonesian people may encounter problems in mastering English because some learning processes do not match its context. English is normally taught and supported by sufficient exposure of its usage. For instance, Indonesia through the curriculum of 1994 emphasized the communicative competence as its outcome [8]. However, people did not have enough supported environment to practice English every day. Moreover, those who lived in 
peripheral area tent to learn almost subjects conventionally and, sometimes, not by using up-to-date teaching learning materials. In simpler words, barriers still exist for rural students to get their educational and vocational success [9]. So, the context does not match the early purpose of English language learning through the curriculum in Indonesia. The other similar cases happened by implementation of recent English curriculum. This problem leads to the next challenge that English teachers have a low English competence and instructional management skill manifested in the way they performed teacher-students less cooperation and minimum understanding for lessons delivered [10]. Inappropriate context may be one of contributors for problems to appear. Besides, there are not enough resources that accommodate students' needs. In addition, teachers' ability to design and develop teaching learning material is considered as insufficient [11].

Those ideas proposed by researchers are truly happened in Indonesia, nowadays. Meanwhile, those problems stated still have a slightly gap. Previous researchers mentioned about English language mastery problems encountered by Indonesian people in general and theoretical ideas. The idea of English curriculum in Indonesia, English teachers' low level of competence and some others mentioned by researchers are merely general idea-based result without providing local voices representing the real challenges faced by peripheral people in Indonesia. This study fills the gap between previous theoretical ideas and real Eastern Indonesian schoolers' voices to get a complete and concrete situation in Indonesian English language education setting. To have a well-ordered thought about Eastern Indonesian students' problems, the preliminary research was conducted. In fact, from 13 students as representatives in this phase, most of them (almost 70\%) found it hard to use English to introduce their selves. Some students were not confident to close their cheating paper while introducing their selves. The others started it well although there were some quite-long pauses due to nervousness during introduction. In addition, this shocking condition grounded by teachers' inability to give a meaningful English language learning during their past educational level. It is clear that they did not have a sufficient English competence due to some factors namely self-confidence, habituation, teaching learning methods, resources and others.

The background brought the understanding that there were still people who need to be helped in order to get opportunities as what others get from this country's relation. They deserve to have career improvement as a part of this blessed nation even though they live far apart at the eastern side. Their lack of English competence is not only because of human factors but also from management factor. The teachers' capability to manage their classes, school leaders' intention to encourage their educators enhancing their skills, students' learning innovation by using recent qualified resources and other related issues contribute to get the education outcomes. There are changes in recent language education from focusing more on teachers, textbooks, conventional learning methods and provided resources into student-centered learning where teachers manage their methods matching them to resent approaches and issues and creating a simple English context where students have chances to practice their English skill [12].
This study presents an empirical situational qualitative related to English language teaching and learning among Eastern Indonesian students. These questions 'what is the real situation of English language education experienced by Eastern Indonesian students?' and 'how could it (the situation) be' become the foundation of undertaking this research.

\section{METHODOLOGY}

This study is a qualitative research-based aiming to get a clear image and condition narratively based on real qualitative data gathered about issues selected. Researchers used, at least, two phases in conducting this study. First, this study began with preliminary study on the context. Here, the focus is on gathering information about the way of Eastern Indonesian students behave in English language learning. Students' engagement, activities, and visible English competence were observed to be described as in-fact condition and context underlining this whole study. Second, this study was continued by core research activities. Researchers prepared concept design, research instruments and analysis design for analyzing and presenting the data. In this phase, there were some activities conducted in order to gain sufficient data representing the real situation of issues as a situational analysis.

To complete the gap between theory and practice related to English language education in Eastern Indonesian schools, this study used a purposive sampling which engaged Eastern Indonesian college students to be a representation in voicing their English education experience. They were one-year college students from interdisciplinary study program at Universitas Kristen Satya Wacana. The number of 33 students were participating in this study. Those participants were divided into two phase such as: preliminary study on 13 students and core research on 20 students.

The data was gathered by using three kinds of instruments namely observation, open-ended questionnaire and unstructured interview. This triangulation was conducted to get objective data prior to the analysis process. The observation was undertaken while 13 students were joining English language learning course. They were taught and given tasks as a trigger for the researcher to collect preliminary data about their English competence. Those data became a short framework while researchers continued to use the other instrument, open-ended questionnaire. The questionnaire spread to the rest of participant of this research covered reflective question about their English competence, past teachers' English Language Teaching (ELT) management and resources usage to complete previous short framework.

After sufficient data gathered, researchers proceeded to data analysis which divided into several substantial categories namely students' English competence from participants' reflective answers, real practice of ELT management among Eastern Indonesian students and English teachers' use of resources in their context. Participants' reflective response provided an accurate prediction of their English competence integrated from speaking, listening, reading and writing skills. The data was not displayed one by one skill but it was in a form of simple table consisting low, medium and high integrated English competence. Other categories covered the 
data of eastern Indonesia students enrolled in such an ELT management including teachers' teaching style, teacher provided tasks and students' judgement of ELT management conducted by their teachers. The last category enriching the issues discussed was from teachers' use of resources to teach English.

\section{RESULT AND DISCUSSION}

Open-ended questionnaires were used to get primary data of the core research taken from participants who were chosen by purposive sampling technique. They were first year of Eastern Indonesian college students from interdisciplinary study program in Universitas Kristen Satya Wacana Salatiga. Five open questions triggering their perspective, opinion and ideas related to the category provided previously. The presentation of research data was also conducted by dividing into three substantial categories such as students' English competence from participants' reflective answers, real practice of ELT management among eastern Indonesian students and English teachers' use of resources in their context

\section{A. Eastern Indonesian Students' English Competence}

Reflecting from the preliminary study, the participants of $70 \%$ joining English language learning course whose English competence was inadequate. There were problems and mistakes encountered during performing English in daily instruction. By referring to this data, this study tried to crosscheck the preliminary result by conducting English language competence reflection among participants. The data of Eastern Indonesian students' English competence was presented in Table 1.

TABLE I STUDENTS' LEVEL OF ENGLISH COMPETENCE

\begin{tabular}{|c|c|c|c|}
\hline \multirow{2}{*}{$\begin{array}{c}\text { Students } \\
(\mathbf{S})\end{array}$} & \multicolumn{3}{|c|}{ English Language Competence } \\
\hline & $\sqrt{ }$ & Medium & High \\
\hline 2 & & $\sqrt{ }$ & \\
\hline 3 & & $\sqrt{ }$ & \\
\hline 4 & & $\sqrt{ }$ & \\
\hline 5 & $\sqrt{ }$ & $\sqrt{ }$ & \\
\hline 6 & $\sqrt{ }$ & & \\
\hline 7 & $\sqrt{ }$ & & \\
\hline 8 & $\sqrt{ }$ & & \\
\hline 9 & $\sqrt{ }$ & \\
\hline 10 & $\sqrt{ }$ & & \\
\hline 11 & $\sqrt{ }$ & & \\
\hline 12 & $\sqrt{ }$ & & \\
\hline 13 & $\sqrt{ }$ & \\
\hline 14 & $\sqrt{ }$ & & \\
\hline 15 & & & \\
\hline & & & \\
\hline
\end{tabular}

TABLE I, Cont.

\begin{tabular}{|c|c|c|c|}
\hline 16 & & $\sqrt{ }$ & \\
\hline 17 & $\sqrt{ }$ & & \\
\hline 18 & $\sqrt{ }$ & & \\
\hline 19 & & & $\sqrt{ }$ \\
\hline 20 & $\sqrt{ }$ & & \\
\hline Percent & $60 \%$ & $35 \%$ & $5 \%$ \\
\hline
\end{tabular}

The data showed that only 1 participant (5\%) stated that the English language competence is in high level. The participant mastered English well while studying in senior high school and enjoyed learning English by following the teacher's style in teaching learning process.

However, there were 7 participants said differently. Those $35 \%$ of total participant mentioned that they were able to use English for certain cases. A middle position the participants thought was the most suitable to reflect their competence. One said that her English was neither so good nor so bad. There was a student mentioned "I did not really like English subject". It related to the other idea mentioned later about the way teacher teaching English made her bored. Some others stated that they did not practice a lot resulting their lack of English competence.

The rest of participant (12 people, 60\%) considered their selves as low English competence students. A lot of reasons underlining their opinion. Generally, those reasons could be simplified into two factors, i.e. internal and external factors. Students' lack of English competence due to internal factor might be caused from personal efforts. “... I played while teacher was explaining English materials... I ignored the teacher... I did not put my attention to the teacher". A participant also put a sigma that English was difficult to learn, hard to be mastered and fearful as a subject. The others felt that there were some English patterns, meanings and pronunciations becoming so difficult to learn. Moreover, there was a student said that she did not like English so she never did her best to learn or even master it. "... I was never keen on English ... I do not even want to know anything about the subject". Those were the internal factor contributing to their lack of English competence.

The external factor came from schedule allocation, teachers' availability and teaching method. Students shared that there was no sufficient time to practice English so they could not develop their English optimally. "... so many theories... a little expose to outside learning for real object understanding". "... school gave only 2 hours for English subject... It was too short to learn English". Some participants complained about the way their teachers taught English. They felt that their teachers were just explaining the material without confirming whether or not the students understood the lesson. Their teachers just taught the students with no efforts to make them attracted to or interested in the lesson delivered. One of them said "... and also, my English teacher rarely came to class so I did not improve my English. Teacher availability also becomes a crucial thing to consider. Other participant mentioned that 
school where she belonged to did not have English teacher so the school should hire one from another school. Those all represents the real situation for external factor behind students' lack of English competence

Those ideas were not only happened without any reasons. Behind those statements there were rationales and most of them came from the way teachers manage their English lesson. Students' interest of learning English is determined by the way their teachers present English subject. Students are engaged effectively if there are things attracted their attention. As stated previously, students might have a bad stigma of English lesson unless their teachers are able to modify teaching learning process to be fun, interactive and flexible. Interactivity and flexibility contribute positively to students' English learning [13]. Grounded to the first result about Eastern Indonesian students' English competence, researchers proceed to the ELT management in Eastern Indonesia generated from students' reflective answers.

\section{B. ELT Management in Eastern Indonesian Context}

Previously, research data showed that in some cases teachers' management skill affects students' competence. Hence, the way teachers manage English language teaching and learning should be prioritized as well. ELT management put the basic foundation of management principle from preparing, organizing, actuating (leading) and controlling English language education [14]. Preparation describes teachers' readiness and completion prior to teaching and learning. Organization focus more on how teachers combine teaching materials, methods and some other supported aids. That teachers implement all prepared instruments and begin to interact with students in real educational setting is considered as actuation or leading. Then, controlling plays its role in assessing, evaluating and ensuring that all goals in the process and/or product achieved well.

As the data collected, there were some impressions from students' point of view toward teachers' ELT management. To make it well-organized, this study used six level of learning developed by Benjamin S. Bloom known as Bloom's Taxonomy as analysis framework based on the practice of preparation, organization, actuation and control in educational management. Blooms proposed six level of learning as listed in one of research journals: knowledge, understanding, application, analysis, evaluation and creation [15]. Table 2 presented students' point of view toward Eastern Indonesian English teachers.
TABLE II EASTERN INDONESIAN TEACHERS' ELT MANAGEMENT

\begin{tabular}{|c|c|c|}
\hline No & Bloom's Taxonomy & Explanation \\
\hline 1 & Know & $\begin{array}{l}\text { - Teachers asked students to } \\
\text { memorize some words (new } \\
\text { vocabularies) and/or language } \\
\text { patterns. } \\
\text { - Classroom activities were } \\
\text { conducted in a form of reading } \\
\text { mainly from textbook. } \\
\text { - One-way interaction from } \\
\text { lecture dominated English } \\
\text { lesson. } \\
\text { - Teachers always gave question } \\
\text { to be answered by students. } \\
\text { They were expected to explain } \\
\text { what they know related to the } \\
\text { questions given. }\end{array}$ \\
\hline 2 & Understand & $\begin{array}{l}\text { - Students were demanded to } \\
\text { discuss given topics as } \\
\text { classroom activities. } \\
\text { - Students required to present, to } \\
\text { tell and to stated given topics } \\
\text { in a form of in class } \\
\text { presentation. } \\
\text { - Students summed up what they } \\
\text { listen from recording in } \\
\text { listening section. }\end{array}$ \\
\hline 3 & Apply & $\begin{array}{l}\text { - Teachers gave students tasks to } \\
\text { do in class. }\end{array}$ \\
\hline 4 & Analize & No activity \\
\hline 5 & Evaluate & No activity \\
\hline 6 & Create & 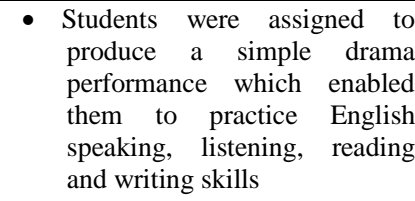 \\
\hline
\end{tabular}

Table 2 presents a clear picture of teacher performance in managing English lesson in eastern Indonesian context. It represented that some English teachers still designed and gave a low-level of English activities. Most activities done in English lesson were categorized under 'know' level from Bloom's Taxonomy. 'Know' is the simplest and very bottom level of learning which only required a little effort and gave onsurface experience. They just memorized, read, answered teachers' questions and explained simple thoughts. Students taught or given activities under this level did not gradually develop their English competence. At a certain point, they stopped learning and felt bored since they need improvements. Students argued that their teachers made them bored, confused and dizzy when they used their chosen teaching method. The teaching method mentioned earlier were the way teachers lectured, assigned many tasks, asked questions most of the time and low initiative to modify their teaching method. Students needs fresh and innovative teaching methods which determined their perspectives on ideal professional teachers. 
Besides, there were some activities delivered under 'understand' and 'apply' level of learning. Activities under those level enabled students to dig more knowledge based on the on-surface knowledge gained from 'know' level of learning. Students are encouraged to have a short discussion while teachers explaining and/or guiding the topic. Presentation in front of the class also became alternative to teach students sharing of ideas to their peers. Moreover, tasks given under 'create' level of learning generated students critical thinking and the way they collaborated any kinds of insight to produce a organized creation. However, based on students' point of view, there was only one activities done under Bloom's Taxonomy 'create' level of learning such as: drama design and performance. If teachers designed teaching learning successively from 'know' up until 'create' level of learning, English language learning might be effectively conducted.

\section{English Teachers' Use of Resources}

Based on data collected, most of the participants stated that their English teachers were commonly used textbook. The use of textbook varied from one teacher to another. Ones used textbook as the only resource they had in teaching English. Surely, this practice did not long last since textbook provided only simple common activities and explanation. Teachers following this path got criticized by students for not modifying English resource. "... my teacher did not change the material from time to time... S/he less modified their resources.... One students commented that her teacher was quite interesting but depending so much on his/her textbook. Teachers who did not adopt the resource and innovate more teaching material ended in stuck of teaching ideas. This kind of practice let to students' unwillingness to struggle in mastering English.

In other side, there was teachers using textbook as a guideline. In this case, teacher did not refer to the material in the textbook but developed their own teaching material using textbook as a 'walkthrough' to balance the contents provided with students' needs. Students felt more comfortable and put their respect on teachers following this kind of practice. Teacher might combine some resources, specially, English books and delivered them through related activities. Some participants also mentioned that their English teachers using up-to-date teaching resource from recent curriculum (KTSP and/or K-13 curriculum).

Fig. 1 showed some kinds of resource used by Eastern Indonesian English teachers.

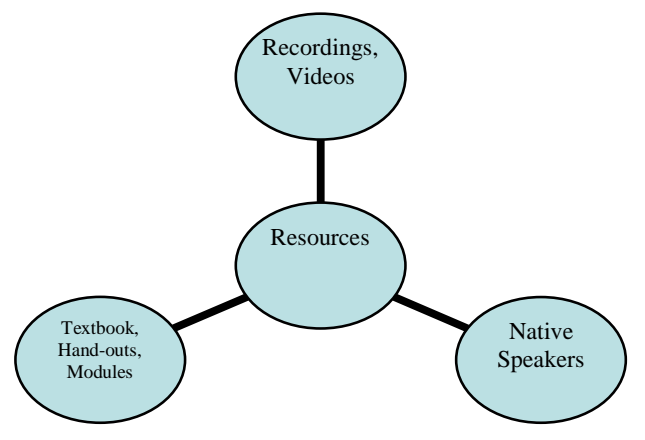

\section{Fig. 1. Kinds of English Teachers' Resources Usage}

English Teachers in Eastern Indonesia could be considered as quite good in choosing resources. Most of the statements from the participants said that their English teacher used their resources well though there were some practices which was not match students' learning style. Fig. 1 showed that there were, at minimum, three kinds of resource used by Eastern Indonesian English teacher. First, they used common textbook, hand-outs and modules. Some of them utilized books provided by Dinas Pendidikan (Education Government Office) adopting recent curriculum. They were also developing English teaching resources based on a guideline book taken from well-known publisher in Indonesia.

Second, some teachers used technology in enriching teaching resource. Teachers commonly used recordings especially when they taught listening and speaking. Students in the classroom were required to pay attention on the recordings and summed up what they had heard. The other technological resource was video. There were teachers using video to stimulate students' imagination, motivation and several English skills. Those practices got positive response from students and made them willing to engage in English lesson. Third, there was a school employed a native English speaker as a teacher. "My teacher did not use any books since he came from USA joining a certain association in Jakarta and developed his own materials in teaching English....

Thus, English teachers' use of resource was good enough to accommodate recent demand of English language teaching and learning. As what was stated earlier that there were challenges in English mastery from students' lack of competence, teachers' ELT management and teachers' use of resources. Nonetheless, there was a potency for English language education be maximized up to an optimal level by managing more teaching and learning methods and resources so students and teachers, mutually, collaborated in an effective in-class and/or out-class English education.

\section{CONCLUSION}

Eastern Indonesian English education is still able to be improved and developed by using several strategies. For enhancing students' English competence, teachers need to innovate and discover rich teaching and learning methods. By doing so, students are motivated and engaged effectively in English lesson while teachers can monitor and control the class well. To get maximized on teaching methods, teachers are required to learn and explore more recent approaches and methods. The last but not least, Eastern Indonesian teachers' use of resources was quite good. They just need to utilize and manifest their resources through meaningful and goal-oriented English education practices. Though the researchers realize that this research result cannot be generalized, at least, there are some empirical situational images represented the real needs of well-managed English education for Eastern Indonesian people. 


\section{ACKNOWLEDGMENT}

In this section, we would like to say thanks to our affiliation, Universitas Kristen Satya Wacana, who gave us opportunities to share, gain and develop theoretical and empirical knowledge through this international conference. A full-hearted gratitude also be given to the participants of this study, 33 Eastern Indonesian college students from interdisciplinary study program in Universitas Kristen Satya Wacana which is divided into two phase participations.

\section{REFERENCES}

[1] J. Melitz and F. Toubal, Native Language, Spoken Language, Translation and Foreign Trade, Journal of International Economics 93, $351-363,2014$

[2] J. Melitz, English As A Global Language, Working Paper No. 2015-05, January 2015, UK: Heriot-Watt University.

[3] A. Begum, Importance of English Language in India: Its Role in Present National and International Set Up, International Journal of Interdisciplinary and Multidisciplinary Studies (IJIMS), Vol.1, No.10, pp. 126-128, 2014.

[4] I. C. Ke, A Global Language without A Global Culture: From basic English to Global English, English as A Global Language Education (EaGLE) Journal, Vol.1, No.1, pp. 65-87, 2015.

[5] J. Smith, English as An International Language (EIL), World Englishes within An International Context, and The Tower of Babel, U-Talk in Summit Online English Language Center, Philippines, February 16 , 2015.
[6] R. Wu, R. Wu and V. T. Le, Challenges of Adults in Learning English as A Second Language: Focus on Adult Education in China, Journal of Language Teaching and Research, Vol.5, No.5, pp. 1132-1138, September 2014.

[7] S. R. Ahmad, Importance of English Communication Skills, International Journal od Applied Research, Vol.2, No.3, pp. 478-480, 2016

[8] Y. Yulia, Teaching Challenges in Indonesia: Motivating Students and Teachers' Classroom Language, Indonesian Journal of Applied Linguistics, Vol.3, No.1, pp. 1-16, July 2013.

[9] C. R. Foertsch, Educational Migration in Indonesia: An Ethnograpgy of Eastern Indonesian Students in Malang, Java, June 3, 2016, Oregon State University.

[10] T. J. Khan and N. Khan, Obstacles in Learning English as A Second Language among Intermediate Students of Districts Mianwali and Bhakkar, Pakistan, Open Journal of Social Sciences, 4, pp. 154-162.

[11] E. Solak, Current Challenges in English Language Learning in Turkish EFL Context, Participatory Educational Research (PER), Vol.2, No.1, pp. 106-115, April 2015.

[12] J. Scheurs and R. Dumbraveanu, A Shift from Teacher Centered to Learner Centered Approach, June 27, 2014, Belgium: Hasselt University.

[13] M. Kurniawan, Students' Perspectives toward The Use of Teacher's Edublog in EFL Learning, 2013, Indonesia: Universitas Kristen Satya Wacana.

[14] T. Brian, Principles of Management, 2015, Saylor Books.

[15] C. J. Staney, Reevaluating Bloom's Taxonomy: What Measurable Verbs Can and Cannot Say about Student Learning, Education Sciences, 6, 37, November 2016. 